\title{
Symbolika namaszczenia głowy i obmycia twarzy przez poszczącego (Mt 6,17) w interpretacji patrystycznej
}

W Mateuszowej Ewangelii Jezus udziela następujących zaleceń dotyczących postu: „Kiedy pościcie, nie bądźcie posępni jak obłudnicy. Przybierają oni wygląd ponury, aby pokazać ludziom, że poszczą. Zaprawdę, powiadam wam, już odebrali swoją nagrodę. Ty zaś, gdy pościsz, namaść sobie głowę i obmyj twarz, aby nie ludziom pokazać, że pościsz, ale Ojcu twemu, który jest w ukryciu. A Ojciec twój, który widzi w ukryciu, odda tobie" (Mt 6,16-18). W wierszu siedemnastym zostaje ujęta postawa poszczącego chrześcijanina w obrazie namaszczenia głowy i obmycia twarzy, w wierszu szesnastym i osiemnastym natomiast postawa ta zostaje opisana przez dwie cechy: pogodę ducha i pokorę.

Przedmiotem naszej analizy jest egzegeza Ojców greckich i łacińskich poświęcona słowom Jezusa w Mt 16,17. Współczesny warsztat, wzbogacony o środki elektroniczne, znacznie ułatwia wgląd, jeśli nie w całość tej egzegezy, to przynajmniej w zdecydowaną jej większość, a zwłaszcza w tę reprezentowaną przez głównych jej przedstawicieli. Egzegeza patrystyczna tego wersetu nie doczekała się szczegółowych badań. $\mathrm{Na}$ jej podstawie pragniemy zrekonstruować patrystyczną teologię dotyczącą powyższych wskazań Jezusa na temat postu. Zadanie to wydaje się tym bardziej uzasadnione, że nawet we współczesnej egzegezie, słowa Mt 16,17 są na ogół komentowane dość oględnie, jako polemika z postawą obłudy i ostentacji, bez wchodzenia w jakieś szczególne subtelności. Przekonuje nas o tym przegląd bibliografii biblijnej i lektura kilku współczesnych komentarzy. W naszej kwerendzie natknęliśmy się

1 Prof. dr hab. Leon Nieścior, pracownik Katedry Teologii Patrystycznej na Uniwersytecie Kardynała Stefana Wyszyńskiego w Warszawie, e-mail: 1.niescior@uksw. edu.pl, ORCID: 0000-0003-4988-9667. 
jedynie na jeden artykuł obcojęzyczny i jeden polskojęzyczny poświęcony dokładnie temu wersetowi ${ }^{2}$.

Ojcowie chętnie komentują Jezusowy nakaz namaszczenia głowy i obmycia twarzy (Mt 6,17) w kontekście Jego zachęty do radości i pokory podczas praktyki postu (Mt 6,16.18). Komentatorzy są wrażliwi na bezpośredni kontekst słów Jezusa. Odwołując się do Mt 6,17-18, Orygenes powiada: „Jeśli chcesz pościć, pość po chrześcijańsku”3. Mając duży wpływ na potomnych, Aleksandryjczyk upatruje chrześcijański sens postu, jak jeszcze zobaczymy, w wiernym wypełnieniu jego ewangelicznych zaleceń na ten temat.

\section{Pokora poszczącego}

Nadmieniona powyżej krytyka przez Jezusa w Mt 6,16-18 faryzejskiej ostentacyjności i próżności wymaga osobnego potraktowania. Staje się przedmiotem szczególnej uwagi naszych komentatorów. Zarówno obraz namaszczenia, jak i umycia twarzy wyraża zalecane przez Mistrza ukrywanie dobrych uczynków. W wierszu szesnastym i siedemnastym Jezus wyraźnie przeciwstawia sobie ,pokazywanie” postu ludziom i Bogu.

Chromacjusz z Akwilei, jak inni autorzy, wyjaśnia, że w Mt 6,17-18 Jezus zachęca do pokory, aby chrześcijanie nie pościli dla własnej chwały, ale dla Boga. Dalej wskazuje na nieuniknioną alternatywę: „Właściwie, to jeden jest cel - jak się wydaje - postu tak u tego, co z myślą zbożną pości tylko dla Boga, jak i u tego, który poszcząc pragnie się ludziom przypodobać"4. Zdaniem kaznodziei ostatecznie nie ma pośrednich postaw: albo człowiek będzie szukał Boga, albo siebie.

Nasi pisarze powtarzają Jezusową zachętę do dyskrecji podczas umartwienia. Celem owych gestów jest to, ,abyśmy, jeśli się uda, zakryli dzieło poszczenia, a nawet utrapienia ciała i duszy, pogodą oblicza"'. Chrystus „kazał namaścić głowę nie w tym celu, byśmy koniecznie to czynili, lecz byśmy z każdej strony usilnie starali się ukryć ten uczynek”6 Zresztą „On

2 E. Levine, The Theology of Fast Day Cosmetics (Mt 6:16-18), ,Journal of Ritual Studies” 13/1 (1999) s. 1-6; M. Żywica, Post z ,umyta i namaszczona twarza” (Mt 6, 16-18), „Warmińskie Wiadomości Diecezjalne” 84 (2006) s. 75-78.

3 Origenes, Homiliae in Psalmos XVIII 4. Gdzie indziej Aleksandryjczyk wskazuje na specyficznie chrześcijańskie dni postu: środę, piątek i wszystkie dni Wielkiego Postu. Por. Origenes, Homiliae in Leviticum X 2, PSP 31/2, s. 148.

4 Chromatius Aquileiensis, Sermones XV 1, PSP 49, s. 160.

5 Chromatius Aquileiensis, Sermones XV 2, PSP 49, s. 161.

6 Joannes Chrysostomus, In Matthaeum homiliae XX 1, ŹMT 18, s. 256. 
sam potwierdził czynem to, co nakazał słowami: pościł przez czterdzieści dni, pościł w ukryciu (Mt 4,1-2), [...] dokonał tego jako najbardziej ze wszystkich pozbawiony próżności"’.

Pewne wyobrażenie o takiej postawie daje Piotr Chryzolog, który wyjaśnia, że nie da się dosłownie wypełniać słów Jezusa w Mt 6,17, choć istnieje zwyczaj namaszczania twarzy. Żeby jednak chrześcijanin nie popadł w obłudę i nie udawał smutku podczas postu, powinien okazywać pogodne usposobienie, na przykład właściwe człowiekowi, który rano, będąc wyspany, spożywa radośnie śniadanie ${ }^{8}$.

Późniejsi bizantyjscy pisarze dodają kolejne szczegóły takiej postawy. Zdaniem Grzegorza Palamasa (1296-1359) namaścić głowę i obmyć twarz to zrezygnować z pokazywania innym oznak swego umartwienia widocznych na twarzy, jak bladość, suchość skóry czy wrażenie posępności i surowości. Tak należy czynić, aby nie zbierać pochwał od ludzi, które mogą obudzić próżność ${ }^{9}$. W kompilatorskim tekście, być może przejętym od wcześniejszego autora, Focjusz (810-891) stwierdza, że ukrywamy umartwienie przez okazywanie na zewnątrz radości i pogody ducha. Jego przykry, uciążliwy i odstręczający charakter przysłaniamy zapałem i radością, sprawiamy wrażenie łatwości podejmowanych wyrzeczeń ${ }^{10}$.

Zdaniem Jana Chryzostoma Jezus, zalecając dyskrecję w pełnieniu dobrych uczynków, w poście i modlitwie zalecił wyższy jej stopień aniżeli w jałmużnie. W jałmużnie zaleca unikać pokazywania się przed ludźmi, w pozostałych uczynkach natomiast nie tylko unikać, ale świadomie ukrywać te uczynki. Ta różnica zachodzi z przyczyn praktycznych. Zdaniem kaznodziei ,jałmużnę nie zawsze da się ukryć, a post i modlitwę zawsze"11. Owo działanie ukrywające dobre uczynki zostaje wyrażone gestem namaszczenia i obmycia, czego Złotousty, jak już wcześniej wskazaliśmy, nie rozumie dosłownie.

Nie wszyscy Ojcowie reprezentują pogląd, że post da się zawsze ukryć przed innymi. Bazyli Wielki stwierdza, że może zajść taka sytuacja, iż ktoś chce pościć tylko z miłości do Boga, i to w ukryciu, ,ale rzecz staje się wbrew jego woli jawna". Jak ma wtedy postąpić? Zdaniem biskupa Cezarei przykazanie, które ma na celu leczyć z choroby próżności, nie odnosi się w tym przypadku do ludzi szczerze miłujących Boga, więc ich uczynki mogą zostać odsłonięte, tym bardziej, że dzieje się to wbrew ich

\footnotetext{
Joannes Chrysostomus, In Matthaeum homiliae XX 1, ŹMT 18, s. 256.

8 Por. Petrus Chrysologus, Collectio sermonum VII 4, PL 52, 205: ,sed habitu prandentis vult celari ieiunium christiano".

9 Por. Gregorius Palamas, Homiliae VII 10.

10 Por. Photius, Epistulae 129.

11 Joannes Chrysostomus, In Matthaeum homiliae XX 1, ŹMT 18, s. 255.
} 
woli. Jezus bowiem wypowiada też inne słowa: „Nie może się ukryć miasto położone na górze. Nie zapala się też światła i nie stawia pod korcem" (Mt 5,14-15) ${ }^{12}$.

Niekiedy trudno jest uniknąć postu na oczach innych. Na przykład pasterz, kiedy wzywa swój lud do postu, sam powinien przyłączyć się do tego wspólnego umartwienia, a zatem $\mathrm{z}$ racji duszpasterskich może pościć w sposób jawny czy nawet publiczny. Cezary z Arles stawia pytanie, czy takim postępowaniem nie narusza zalecenia Jezusowego w Mt 6,17. Odpowiada, że wtedy nie postępuje wbrew Ewangelii, ponieważ zachowuje samą istotę jej zalecenia. Dobrych uczynków nie spełnia dla chwały ludzkiej, ale po to, aby wyjednać u Boga miłosierdzie dla grzeszników. Żywiąc taką intencję, choć czyni coś jawnie, czyni jakby w ukryciu ${ }^{13}$.

W Mt 6,16 Jezus wskazuje na ujemne skutki umartwień podejmowanych dla chwały ludzkiej. Tacy ludzie pozbawiają się nagrody u Boga. Nasi komentatorzy przyglądają się skutkom takiej próżności. Pod jej wpływem dobre uczynki, jakimi jest post, nie przyniosą pożytku, nie pozostawią „owocu na przyszłe życie, ale kończą się na ludzkich pochwałach" ${ }^{14}$. Serce ludzkie doznaje wtedy rozdwojenia ${ }^{15}$. Tymczasem post praktykowany w pokorze pozwala uwolnić się z więzów $\mathrm{zła}^{16}$.

Kasjodor wiąże Mt 6,17 z Augustyńską interpretacją przypowieści o pannach roztropnych i nierozsądnych (Mt 25,1-13) ${ }^{17}$, nadając symbolice związanej z olejem znaczenie eschatologiczne. Jest „olejek grzesznika” (Ps 141,5) i olejek sprawiedliwego. Tym pierwszym pozostaje upodobanie w cudzych pochlebstwach, które rozmywają prawdę i prowadzą do szkodliwej próżności, tym drugim - szukanie chwały Bożej, co sprawia piękno duszy, prawdziwą chwałę i zbawienie. Dobrą oliwę posiadały w swoich lampach panny roztropne, ponieważ spełniały dobre uczynki ze względu na oblubieńca. Były gotowe przyjąć napomnienie ze strony ludzi sprawiedliwych, praktykowały miłosierdzie, dlatego Pan nie odmówił im wieczystej uczty. Tymczasem panny nierozsądne, na nieszczęście dla nich, uwierzyły w pochlebstwa innych. Zabrakło dobrej oliwy w ich lampach. Nie mogły ofiarować swego życia pogrążonego w ciemnościach oblubieńcowi, który jest Panem prawdziwego światła ${ }^{18}$. Wprawdzie Kasjodor dość nie-

12 Por. Basilius Caesariensis, Asceticon magnum, PG 31, 1221.

13 Por. Caesarius Arelatensis, Sermones 146, 1.

14 Basilius Caesariensis, De ieiunio: homilia I 2, Post jako praktyka duchowa, s. 56.

Por. Petrus Chrysologus, Sermones VII 2, Post jako praktyka duchowa, s. 92.

15 Por. Augustyn Hipponensis, De sermone Domini in monte XII 40, PSP 48, s. 100.

16 Por. Eusebius Caesariensis, Commentarius in Isaiam II 47 (in Is 58,5).

17 Por. Augustinus Hipponensis, De diversis quaestionibus 59, 3.

18 Por. Cassiodorus, Expositio psalmorum (in Ps 140,6). 
wyraźnie łączy Mt 6,17 z Mt 25,1-13, posługując się wspólnym dla tych miejsc symbolem oleju, ale z jego interpretacji wynika coś i dla naszego wątku. Chrześcijanin, który praktykuje post i namaszcza głowę dobrym „olejkiem”, szuka chwały Bożej, aby dostąpić nagrody wiecznej u Boga.

\section{Czystość wewnętrzna}

Obok namaszczenia głowy Jezus zachęca poszczącego chrześcijanina do obmycia twarzy. Augustyn z Hippony powiada, że „,należy rozumieć to przykazanie namaszczenia głowy i mycia twarzy jako odnoszące się do człowieka wewnętrznego. A więc namaszczanie głowy odpowiada radości, mycie twarzy zaś czystości”19. Niektórzy traktują oba te gesty łącznie, inni - oddzielnie, jednak Ojcowie rozumieją je oba w sensie przenośnym, a nie dosłownym.

Niemałe znaczenie dla interpretacji Mt 6,17 ma przenośne rozumienie przez naszych komentatorów w tym miejscu fizycznej głowy i twarzy. Pod tym względem są dość zgodni. Dla Hilarego z Poitiers głowa, to ,świadomość naszego życia”, „siedlisko zdolności poznawania”20 i „ośrodek życia, roztropności i wszystkich zmysłów"21, dla Ambrożego z Mediolanu „miejsce, gdzie znajduje się rozum mądrego człowieka”22, dla Hieronima - „władze naszego serca"23. Dla Augustyna głowa oznacza myśl i umysł, czyli to, „,co w duszy góruje” i zarządza w człowieku resztą ${ }^{24}$, z kolei twarz - „serce, którym ma zobaczyć Boga"25. Dla dużo późniejszego pisarza, Grzegorza Palamasa, głowa oznacza władzę dyskursywną, właściwą rozumowi jako zwierzchnikowi duszy, twarz natomiast - władzę wyobraźni, w której znajduje się siedziba zmysłowych poruszeńn ${ }^{26}$. Nie ulega wątpliwości, że głowa i twarz, te najsubtelniejsze części ludzkiego ciała, są rozumiane przez Ojców symbolicznie i oznaczają najwyższe duchowe władze w człowieku. Obmycie twarzy symbolizuje więc oczyszczenie ludzkiego wnętrza.

19 Augustinus Hipponensis, De sermone Domini in monte XII 42, PSP 48, s. 101.

20 Hilarius Pictaviensis, Commentarius in Matthaeum V 2, PSP 63, s. 65.

21 Hilarius Pictaviensis, Tractatus super Psalmos (in Ps 140,9).

22 Ambrosius Mediolanensis, De Helia et ieiunio X 36, VoxP 34-35 (1998) s. 484.

23 Hieronymus Stridonensis, Commentarii in Evangelium Matthaei (in Matth. 6,17), ŹMT 46, s. 34.

24 Augustinus Hipponensis, De sermone Domini in monte XII 42, PSP 48, s. 101.

25 Augustinus Hipponensis, De sermone Domini in monte XII 42, PSP 48, s. 101.

26 Gregorius Palamas, Homiliae VII 11. 
Orygenes wiąże Jezusowe zalecenie, aby „umyć swą twarz”, ze słowami św. Pawła zachęcającymi do tego, aby z odsłoniętą twarzą wpatrywać się w chwałę Pańską (2Kor 3,18) ${ }^{27}$. Wolno dostrzec w tej subtelnej uwadze zachętę do tego, aby chrześcijanin szukał w ascezie chwały Pańskiej, odrzucając preteksty do szukania własnej chwały. Tak oto egzegeta trzyma się ściśle kontekstu słów Jezusa, który zachęca do owych gestów właśnie ze względu na wymóg pokory.

„Odsłonięta" przez obmycie twarz to twarz nieukrywająca niczego, twarz szczera, w przeciwieństwie do faryzejskiej twarzy. Ojcowie zwracają uwagę także i na ten aspekt Jezusowej symboliki. Bazyli Wielki powiada:

Nie zakrywaj twarzy jak obłudnicy. Zakrywasz twarz, gdy zasłaniasz wewnętrzne nastawienie zewnętrznymi pozorami i kłamstwem jak zasłoną. Aktor w teatrze udaje inną osobę: jest niewolnikiem, a często udaje pana, albo jest zwyczajnym człowiekiem, a udaje króla. Tak samo w życiu wielu jak na scenie robi widowisko ze swojego życia, ale co innego ma w sercu, a co innego udaje przed ludźmi. A więc nie zakrywaj twarzy. Jaki jesteś, takim się pokazujer ${ }^{28}$.

Umycie twarzy podczas postu, dokonane w sensie przenośnym, jest odrzuceniem pozoranctwa i zakłamania, a stanięciem w prawdzie przed Bogiem i bliźnim.

Do szczerości sumienia Ambroży dodaje kolejny element symboliki czystej twarzy, mianowicie czystości duchowej. Element ten wydaje się być najbardziej oczywisty, choć nie wynika z bezpośredniego kontekstu Mt 6,17. Twarz odsłania stan naszego sumienia: jest cichą mową naszego wnętrza, czy to wtedy, gdy bolejemy nad grzechem, czy wtedy, gdy radujemy się niewinnością. Jednak tylko wtedy jest pożyteczne odsłonięcie wnętrza i twarzy, gdy wnętrze to oczyściło się ze zła. Obmyć twarz to odsłonić swoje wnętrze, ale takie, które zostało już oczyszczone, zniekształcić swoją twarz natomiast to udawać na zewnątrz to, czego nie ma wewnątrz. Ambroży przeciwstawia obmycie (lavare) twarzy jej zniekształceniu (exterminare). Tak oto dwie rzeczy idą w parze w symbolice omawianego gestu: obmycie twarzy, czyli oczyszczenie z grzechów duszy i sumienia, oraz jej odsłonięcie, czyli szczerość ${ }^{29}$.

Niektórzy komentatorzy skupiają się na samej czystości duchowej wyrażonej przez umycie twarzy. Chromacjusz z Akwilei powiada: „Stąd umywać twarz znaczy, że powinniśmy mieć oblicze serca naszego czyste

27 Por. Origenes, Homiliae in Leviticum X 2, PSP 31/2, s. 147.

28 Basilius Caesariensis, De ieiunio homilia I 2, Post jako praktyka duchowa, s. 56.

29 Ambrosius Mediolanensis, De Helia et ieiunio X 36, CSEL 36/2, s. 432. 
od wszelkich brudów grzechowych i od niechlujstwa występków i obnosić wszędzie samo sumienie czyste, abyśmy mogli okazać prawdziwe radość i wesele niebieskie, i pogodę Ducha Świętego w nas odbite" ${ }^{30}$. Z kolei Augustyn: „Tak przeto i twarz umyje [...] nie kładąc przed siebie zasłony utkanej ze słabości zaciągniętej brudami, ale będzie mocny i stały dzięki czystości i prostocie. Wszak powiedział Pan: «Obmyjcie się, czyści bądźcie! Usuńcie zło uczynków waszych sprzed moich oczu!» (Iz 1,16)"31. Znamienne, że biskup Hippony przytacza następnie 2Kor 3,18 jak powyżej Orygenes. Aleksandryjczyk dostrzegał w obmytej twarzy symbol pokory i prostoty nakazującej szukać tylko chwały Bożej, podczas gdy ubogacony o dalszą tradycję Hippończyk - zarówno prostoty, jak i w ogóle moralnej czystości ${ }^{32}$.

Dopatrując się w obmyciu twarzy symbolu ogólnej czystości moral-

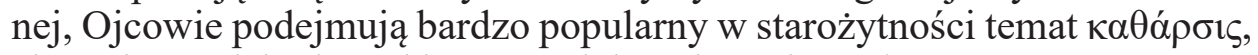
choć nieco odchodzą od bezpośredniego kontekstu słów Jezusa w Mt 6,17. W subtelnym rozdzielaniu symboliki wody i oleju nietrudno zauważyć u niektórych z nich pewną wewnętrzną logikę. Takie rozróżnienie spotykamy na przykład u Hilarego z Poitiers, który stwierdza, że zalecając obmycie twarzy, Pan wymaga od nas czystości sumienia niczym niezabrudzonego, a zalecając namaszczenie głowy, nakazuje, abyśmy stawali się doskonali zarówno pod względem nauki, jak i postępowania. Olej, karmiący ogień, przynosi światło. Tak i zdrowa nauka w połączeniu $\mathrm{z}$ dobrym postępowaniem przygotowuje nam chwałę niebieską. To one niejako namaszczają głowę olejem, określając nasze życie i świadomośćc $c^{33}$. Dla Hieronima i innych obmycie twarzy wyraża wyzbywanie się wad i grzechów, a namaszczenie olejem - pielęgnowania cnót ${ }^{34}$. Jeden gest przedstawia negatywny aspekt pracy wewnętrznej, drugi - pozytywny. Odwołując się do takiej przeciwstawności, Grzegorz Palamas dodaje, że prawdziwy post usuwa nie tylko same namiętności, ale i ich przyczyny tkwiące w przewlekłych myślach i poruszeniach, przez co przepędza też demony ${ }^{35}$.

Poświęcając Mt 6,16-18 sporą część swojej homilii, Chryzostom zaczyna ją od rachunku sumienia i wzbudzenia skruchy u słuchaczy. Chrześcijanie

30 Chromatius Aquileiensis, Sermones XV 3, PSP 49, s. 162.

31 Augustinus Hipponensis, De sermone Domini in monte XII 42, PSP 48, s. 101.

32 Por. Augustinus Hipponensis, De sermone Domini in monte XII 42, PSP 48, s. 101. Również Hieronim przytacza 2Kor 3,18 w podobnym kontekście (Commentarii in prophetas minores. In Malachiam, in 2, 3-4).

33 Por. Hilarius Pictaviensis, Tractatus super Psalmos (in Ps 140,9).

34 Por. Hieronymus Stridonensis, Commentarii in Evangelium Matthaei (in Matth. 6,17), ŹMT 46, s. 34.

35 Por. Gregorius Palamas, Homiliae VII 11. 
mogą być jeszcze gorsi od żydowskich obłudników, gdyż niektórzy z nich praktykują podwójną obłudę. Po pierwsze, w ogóle nie poszczą, a po drugie, udają post, zachowując posępny wyraz twarzy w okresie przepisanych umartwień. Przy okazji Złotousty, w porywie kaznodziejskiej gorliwości, krytykuje kobiety, które „niszczą swą twarz bielidłem i różem”. Zdaniem kaznodziei popełniają podwójną winę, bo nie tylko szkodzą sobie, postępując wbrew Mt 6,16-18, ale i innym, uwodząc ,rozpustnych młodzieńców"36. Wypowiedź Złotoustego jest przykładem bardzo kaznodziejskiego zastosowania rozpatrywanego przez nas logionu Jezusa. Refleksja Ojców jest niejednorodna, rozciąga się od teoretycznych spekulacji aż po moralne pouczenia.

\section{Radość namaszczonego}

W przeciwieństwie do ponurego wyglądu namaszczona i umyta twarz poszczącego wskazuje na pogodę ducha. Szczególnie gest namaszczenia twarzy wyraża tę radość. Jak zaznacza Chryzostom, Chrystus wypowiada słowa o poście nie po to, abyśmy rzeczywiście namaszczali twarz, bo żaden chrześcijanin tego nie robi, ale po to, abyśmy okazywali zadowolenie i radość ducha, a nie byli posępni ${ }^{37}$. W podobnym sensie i Augustyn stwierdza, że zalecone przez Jezusa gesty odnoszą się „,do człowieka wewnętrznego" 38 .

Tradycja starotestamentalna, czy w ogóle kultura bliskowschodnia, wiązała namaszczenie z pewną regeneracją, odświeżeniem. Było ono częścią praktykowanej toalety przejawiającej walory zarówno zdrowotne, jak i estetyczne. Namaszczano ciało po kapieli, dla trwalszego nawilżenia skóry. Ten zabieg kojarzył się też z atmosferą odświętnej radości. Na takie jego rozumienie w tradycji biblijnej wskazuje Jan Chryzostom: „U przodków istniał zwyczaj, by się zawsze namaszczać, gdy radowali się i cieszyli (co widać na przykładzie Dawida i Daniela), dlatego [Chrystus] kazał namaścić głowę" "39. Również Hieronim odnosi się do kontekstu kulturowego, rozpatrując Jezusowe zalecenie: „Mówi stosownie do zwyczaju panującego w prowincji palestyńskiej, gdzie w dni świąteczne zwykle namaszczają

36 Joannes Chrysostomus, In Matthaeum homiliae XX 1, ŹMT 18, s. 255.

37 Por. Joannes Chrysostomus, Expositiones in Psalmos (in Ps 46,2), PG 55, 208 :

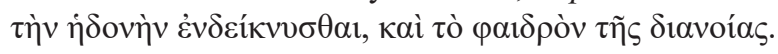

38 Augustinus Hipponensis, De sermone Domini in monte XII 42, PSP 48, s. 101.

39 Joannes Chrysostomus, In Matthaeum homiliae XX 1, ŹMT 18, s. 256. Por. Photius, Epistulae 129. 
głowy. Poleca więc, abyśmy poszcząc, wyglądali na radosnych i świątecznie" ${ }^{40}$. Nawiązuje do oczywistych w starożytności praktyk.

Wskazując na Jezusową zachętę do radości w Mt 6,16-17, Ojcowie chętnie odwołują się do „olejku radości” wspomnianego w Ps 45,8. Już Orygenes wiąże „namaszczenie” twarzy przez poszczącego chrześcijanina z tym właśnie olejkiem, którym Bóg namaszcza swojego wybranego ${ }^{41}$. Pewnie idąc za Orygenesem, również i Hieronim dostrzega w oleju symbol radości poszczącego, nawiązując paradoksalnie do olejku, którym Bóg namaszcza swego wyznawcę, zastawiając obfitą ucztę na oczach wrogów (Ps 23,5). Olejek ten stanowi dla niego także symbol światłości niedostępnej dla grzeszników (Ps 141,5), których pewnym rodzajem są także heretycy ${ }^{42}$.

Owo powiązanie radości poszczącego chrześcijanina wyrażonej przez „namaszczenie głowy” ze starotestamentalną ideą namaszczenia przez Boga swego wybranego stanie się pewnym standardem w egzegezie patrystycznej. W różnych scholiach i katenach spotykamy często takie wyjaśnienie Mt 6,17, czego przykładem są fragmenty zebrane w IX wieku przez Focjusza. Powtarza się w nich nawiązująca do psalmów symbolika namaszczenia i obmycia, która wyraża duchową radość i wewnętrzną satysfakcję z postu ${ }^{43}$. Kolejni komentatorzy powtarzają wyjaśnienie, u początku którego stoi wykładnia Orygenesa.

Tak oto Ojcowie tworzą pewną tradycję egzegezy, kiedy łączą, idąc za słowami Jezusa, post z radością wyrażoną przez namaszczenie. Czy samo połączenie tych dwóch rzeczy, osobno istniejących w Starym Przymierzu, jest dopiero dziełem Nowego Przymierza? Niektórzy z Ojców, jak Chromacjusz z Akwilei, próbują doszukiwać się związku namaszczenia $\mathrm{z}$ postem już $\mathrm{w}$ tradycji starotestamentalnej. Biskup italski wymienia Judytę i Esterę (Jdt 12,7; Est 4,16), które jego zdaniem pościły, dokonując przy tym gestu namaszczenia głowy czy obmycia twarzy. Wspomina też Daniela i jego towarzyszy, których twarz zadziwiająco piękniała z upływem kolejnych dni postu (Dn 1,12-15) ${ }^{44}$. Nie występują jednak wzmianki w Biblii, także - wedle naszej wiedzy - w jej starożytnych przekładach na grekę i łacinę donoszące o zastosowanym w tych sytuacjach namaszczeniu. Owszem, opisuje się w Septuagincie, że na przykład Estera (Est 4,17k) po-

40 Hieronymus Stridonensis, Commentarii in Evangelium Matthaei (in Matth. 6,17), ŹMT 46, s. 34.

41 Por. Origenes, Homiliae in Leviticum X 2, PSP 31/2, s. 147.

42 Por. Hieronymus Stridonensis, Commentarius in Ecclesiasten (in Eccl 9,7); Hieronymus Stridonensis, Commentarii in Evangelium Matthaei (in Matth. 6,17), ŹMT 46, s. 34.

43 Por. Photius, Commentarii in Matthaeum, fragm. 23.

44 Por. Chromatius Aquileiensis, Sermones XV 2, PSP 49, s. 161. 
sypała się popiołem i zmierzwiła włosy podczas postu, a po jego zakończeniu odzyskała swoją urodę (Est 5,1a). Być może z racji pewnej retoryki komentator przenosi postawę poleconą przez Jezusa na zachowanie sławnych postaci Starego Przymierza, chcąc nadać jej pradawny charakter i widzieć w ich gestach zapowiedź postawy chrześcijańskiej.

Nie brakuje w starożytnych komentarzach motywacji, dlaczego poszczący chrześcijanin „namaszcza głowę”, czyli napełnia się radością. Odpowiedź znajdujemy w bezpośrednim kontekście słów Jezusa wskazującym na odwrotność chrześcijańskiego postępowania w stosunku do niewłaściwej postawy niektórych poszczących Izraelitów. Przeciwstawia On radość i pokorę swoich uczniów posępnemu wyrazowi twarzy oraz próżności i obłudzie faryzeuszy. Podobnie przeciwstawia dyskrecję swoich uczniów w umartwieniu żydowskiej ostentacyjności. W Prawie mówi się wiele o posypywaniu popiołem, worze pokutnym i innych gestach towarzyszących umartwieniu. W tamtejszym świecie postawa pokuty i żałoby wiązała się z pewną spektakularnością i teatralnością, co mogło prowadzić do spłycenia postu. Jezus wprowadza nowe prawo, prawo ducha, nadając umartwieniu charakter bardziej osobisty i duchowy.

Antytetyczny charakter wypowiedzi Jezusa, jak zresztą całego Jego kazania na Górze (Mt 5-7), udziela się także jej starożytnym komentatorom, którzy mówią o radości chrześcijan podczas postu w kontraście do obłudnej posępności innych. Podobnie akcentują jej duchowy charakter kontrastujący ze stanem pociechy doznawanej przez ludzi, którzy kierują się przyziemnymi motywami w swoich trudach. Nasi autorzy konstatują: „A więc poszczący niech się weseli wewnętrznie, bo tym samym i tak poszcząc odwraca się od uciech świata i poddaje się Chrystusowi, skoro pragnie On dając to polecenie, aby miał i w poście głowę namaszczoną"45. „Jasne jest, że te przykazania kierują całą naszą intencję ku radościom wewnętrznym, abyśmy szukając nagrody na zewnątrz, nie upodobnili się do tego świata, i żebyśmy nie utracili przyrzeczonej szczęśliwości, o tyle trwalszej i silniejszej, o ile bardziej jest wewnętrzna, poprzez którą wybrał nas Bóg, abyśmy się stali podobnymi do obrazu Jego Syna" (Rz 8,29) ${ }^{46}$. Namaszczenie staje się obrazem przemiany umysłu i serca poszukującego najprawdziwszego dobra i znajdującego go raczej w Bogu i w swojej duszy, a nie w świecie zewnętrznym.

Podejmując obszerny temat radości duchowej w kontekście Mt 6,16-17, nasi komentatorzy często wychodzą poza ścisły kontekst polemiki z faryzejską posępnością i obłudą. Wskazują na rozmaite motywy radości poszczącego chrześcijanina. Uczeń Jezusa cieszy się z postu, który jest

45 Augustinus Hipponensis, De sermone Domini in monte XII 42, PSP 48, s. 101.

46 Augustinus Hipponensis, De sermone Domini in monte XII 40, PSP 48, s. 100. 
pewnym darem. Bazyli Wielki zachęca: „Biegnij więc z radością do darowanego ci postu. Post to starodawny dar, jednak ani się nie przedawnia, ani się nie starzeje, ale nieustannie się odnawia i kwitnie" ${ }^{47}$. Radość postu jest cechą ludzi, którzy podążają do świętości, przez swoją odwagę odnoszą zwycięstwo, poddają się leczeniu pokonującemu chorobę grzechu ${ }^{48}$. Ojcowie często wygłaszają laudację postu, opisując jego duchowe i moralne dobrodziejstwa w tym celu, aby chrześcijanie chętnie i radośnie go podejmowali ${ }^{49}$.

Warto zaznaczyć, że namaszczenie olejem, które w Ewangelii symbolizuje radość z umartwienia ciała uzdrawiającego duszę, nie było czymś obcym w ówczesnej medycynie. Przeciwko różnym dolegliwościom lekarze zalecali choremu namaszczenie olejem w stanie na czczo ${ }^{50}$. Chrystus posłużył się obrazem prostych zabiegów przynoszących ulgę ciału, aby wskazać na potrzebę uzdrawiania duszy za pomocą środków, które na końcu przynoszą także wytchnienie i radość.

W kazaniach Piotra Chryzologa znajdujemy ciekawą psychologię twarzy smucącej się podczas postu:

[Chrystus] nie wymaga zadowolonej miny, ale przestrzega przed udawanym wyrazem twarzy. Smutna twarz wskazuje na wymuszony, nie dobrowolny post. Jeśli ktoś chce pościć, dlaczego miałby być smutny? A jeśli nie chce, po co pości? Zasłużył sobie na udrękę, w jakiej żyje, skoro zmienił swoją cnotę $\mathrm{w}$ wadę, prawdę w kłamstwo, nagrodę w szkodę, przebaczenie w grzech ${ }^{51}$.

Zdaniem kaznodziei Jezus krytykuje ponurą minę poszczącego nie tyle za samą minę, co za jej przyczynę, która tkwi w niewłaściwej motywacji postu. Każdy inny motyw postu aniżeli ten ewangeliczny, czyli podobania się Bogu, będzie frustrował człowieka i zniechęcał do dalszego umartwienia, tak iż post stanie się wymuszony, sztuczny i smutny. Z kolei przyjęty motyw ewangeliczny postu będzie coraz bardziej pociągać wolę i sprawiać radość w następstwie osiąganych dóbr duchowych.

U Focjusza pobrzmiewa akcent eschatologiczny w obrazie namaszczonej podczas postu twarzy. Bizantyjski kompilator kojarzy Mt 6,17

\footnotetext{
47 Basilius Caesariensis, De ieiunio: homilia I 2, Post jako praktyka duchowa, s. 56.

48 Por. Basilius Caesariensis, De ieiunio: homilia I 2, Post jako praktyka duchowa, s. 56.

49 Por. np. Pseudo-Joannes Chrysostomus, De ieiunio II, Post jako praktyka duchowa, s. 115.

50 Por. Aëtius Amidenus, Iatricorum liber XII 68; Hippiatrica, Additamenta Londinensia ad hippiatrica Cantabrigiensia 19.

51 Petrus Chrysologus, Collectio sermonum VII 5, Post jako praktyka duchowa, s. 93.
} 
z Koh 9,8: „W każdym czasie niech szaty twe będą białe, olejku też niechaj na głowę twoją nie zbraknie!". Powtarza, że namaszczenie olejem wyraża postawę radości. Nie należy łączyć postu ze smutkiem. Odświętne ubranie się w białą tunikę i namaszczenie twarzy wyraża radosne życie, które opiera się na cnotach, a odsuwa namiętności i grzech. Ten ubiór staje się szata pozwalająca wejść na gody weselne, które oznaczaja ucztę w niebie (Mt 22,1-14) $)^{52}$. Taka interpretacja słów Jezusa w Mt 6,17 odsyła do innych Jego słów na temat postu, którego praktykę wiąże On z własną osobą jako oblubieńca (Mt 9,15).

Tak oto w wykładzie przez Ojców Mt 6,17 znajdujemy dość bogatą refleksję na temat radości płynącej z praktyki chrześcijańskiego postu. Radość ta bierze się zarówno z przyczyny, jak i sposobu oraz celu postu. Radość przynosi najpierw przyczyna sprawcza wskazanego przez Jezusa umartwienia, czyli dojrzała wola Jego ucznia, który szczerze i dobrowolnie pragnie podjąć to umartwienie. Radość daje także sposób praktykowania postu, wolny od hipokryzji, udawania, ostentacji i smutku. Radość ta pomnaża się przez liczne dobrodziejstwa postu, których doznaje się w następstwie, poszcząc w duchu Chrystusa, aż po szczęście przebywania z Bogiem.

\section{Milosierdzie i inne cnoty}

Symbolika oleju i namaszczenia jest bardzo bogata w świecie Biblii i starożytnej kultury, więc możemy z góry przypuszczać, że $w$ interpretacji przez Ojców Mt 6,17 dochodzą do głosu elementy tejże symboliki niezwiązane ściśle z bezpośrednim kontekstem słów Jezusowych.

Nasi autorzy nawiązują do fundamentalnej prawdy, że pierwszym namaszczonym jest Jezus. W swoim drugimi imieniu, „Chrystus”, czyli „Pomazaniec Boży”, nosi tę prawdę, że jest naznaczonym przez Boga mesjaszem i arcykapłanem. Chrześcijanin ma udział w tym namaszczeniu poprzez chrzest. Na związek tych dwóch namaszczeń, Chrystusa i Jego wyznawcy, jeszcze niewyraźnie wskazuje Orygenes: „Poszcząc bowiem powinieneś przystępować do swego Arcykapłana, którego przecież należy szukać w niebie, a nie na ziemi - i za Jego pośrednictwem winieneś składać ofiarę Bogu" ${ }^{53}$. Dalej Orygenes prowadzi dłuższy wywód na temat postu duchowego, który polega na powstrzymaniu się od grzechu ${ }^{54}$. Powyższy związek wyraźniej widać w napisanym w duchu Orygenesa scholium do

\footnotetext{
52 Por. Photius, Amphilochia 41.

53 Origenes, Homiliae in Leviticum X 2, PSP 31/2, s. 148.

54 Por. Origenes, Homiliae in Leviticum X 2, PSP 31/2, s. 148.
} 
Ps 23,5, w którym nieznany autor odnosi się do Chrystusa, namaszczonego przez Boga „olejkiem wesela”. Podobnie zostaje też namaszczona i obmyta twarz poszczącego ${ }^{55}$.

Z powyższą, kapłańską symboliką omawianych gestów koresponduje oryginalna wykładnia Mt 6,16-18 jednego ze współczesnych autorów. E. Levine podkreśla, że posypanie głowy popiołem było w Starym Testamencie i w Talmudzie aktem przebłagania, pokory i pokuty (Joz 7,6; 2Sm 13,19; Hi 16,15-16; Dn 9,3). Posługiwano się popiołem drzewnym. Pokutujący uznawał się za proch i błagał Boga o miłosierdzie. Tymczasem w Talmudzie spotykamy ślady innej, specyficznej symboliki popiołu znanej Żydom współczesnym Jezusowi. Popiół drzewny symbolizował ofiarę, którą Abraham był gotów złożyć z Izaaka, co okazał przez związanie syna i przygotowanie drewna. Jezus nie zaleca posypywania głów popiołem, ale przeciwnie, namaścić głowę i obmyć twarz. Wskazuje zatem na jedyność własnej ofiary i kapłańskiego pośrednictwa oraz na swoje zmartwychwstanie ${ }^{56}$.

Współcześni bibliści odnajdują też w namaszczeniu przez poszczącego chrześcijanina swojej głowy związku z jego własnym kapłaństwem wynikającym ze chrztu. Namaszczenie głowy w Izraelu oddzielało człowieka poddanego temu obrzędowi od reszty i przeznaczało do służby Bożej (Wj 29,7; Kpł 8,12; Lb 3,3; Ps 105,15). Do tej symboliki nawiązuje św. Paweł, uznając, że wszyscy ochrzczeni są przeznaczeni do szczególnych celów Bożych ${ }^{57}$. W tym kontekście post jawi się jako pewien akt ofiarniczy płynący z powszechnego kapłaństwa chrześcijanina.

Gorliwy czytelnik pism Orygenesa, Ambroży z Mediolanu, wiąże jeszcze ściślej wątek namaszczenia Chrystusa z zalecanym przez Niego namaszczeniem się podczas postu. Olejkiem wesela został namaszczony przez Boga Chrystus. I on nakazuje, abyśmy olejkiem wesela przykrywali wszelki smutek: aby nie stwarzać wrażenia, że pościmy dla oka ludzkiego, że smucimy się, gdy dusza doznaje zbawienia, że odnosimy pozorne zwycięstwo, ponieważ kto tryumfuje, nie powinien się smucićc ${ }^{58}$.

W powyższych starożytnych świadectwach związek pomiędzy namaszczeniem chrześcijanina i Chrystusem wynika przede wszystkim z logiki naśladownictwa Mistrza przez Jego uczniów. W dalszej części wyżej przedstawionej wypowiedzi Ambrożego związek ten ma podłoże jeszcze głębsze, bo wprost ontologiczne. Namaszczona głowa chrześcijanina odsyła do mistycznej głowy, którą jest Chrystus jako głowa Kościoła. Namaścić

\footnotetext{
55 Por. Origenes (?), Selecta in Psalmos (fragmenta e catenis) (in Ps 22,5), PG 12, 1264.

56 Por. Levine, The Theology of Fast Day Cosmetics (Mt 6:16-18), s. 2-3.

57 Por. L. Ryken - J.C. Wilhoit - T. Longman, Słownik Symboliki Biblijnej,
} tł. Z. Kościuk, Warszawa 1998, s. 649.

58 Ambrosius Mediolanensis, De Helia et ieiunio X 36. 
głowę, czyli Chrystusa, to wyznać Jego bóstwo ${ }^{59}$. Podobne zapatrywanie przejawia Bazyli Wielki, wyjaśniając w swojej mowie do wiernych zalecenie Jezusa z Mt 6,17: „Te słowa wzywają cię na misteria. Pomazaniec się namaścił, posłany z nieba się obmył. Zastosuj ten nakaz do duchowych członków. Obmyj duszę z grzechów. Namaść głowę świętym olejkiem, aby stać się uczestnikiem Chrystusa i w ten sposób przystąp do postu"60. Omawiany symbol postrzega biskup Cezarei w świetle tajemnicy Kościoła jako mistycznego Ciała Chrystusa. Sam post nabiera więc także głębszej perspektywy eklezjalnej.

Wracając do Orygenesa, to w innej wypowiedzi Aleksandryjczyk, wskazując na owoce zjednoczenia z Chrystusem, odwołuje się do Ps 141,5: „olejek występnego niech nigdy nie ozdabia mojej głowy”. Kiedy dobrze pościmy, wtedy nasza głowa zostaje namaszczona godnym olejkiem od Boga, a nie olejkiem grzesznika. W takim to duchowym sensie obmywamy swoją twarz, co sprawia, że jesteśmy radośni, a nie posępni. Dobry i miły Bogu post to taki, w którym przede wszystkim nie karmimy w sobie

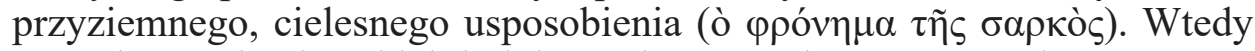
wyrzekamy się ziemskich i cielesnych rzeczy, które utrzymują nasze myślenie w takim usposobieniu. Tego rodzaju post otwiera drogę do rzeczy duchowych i świętych, dostępnych w Chrystusie ${ }^{61}$.

Jak widzimy, duchowe namaszczenie umartwiającego się chrześcijanina daje mu udział w tajemnicy Boga, który okazuje swoją hojność w Chrystusie. Szczodrość ta spełnia się w Jego miłosierdziu. Olej jest także symbolem miłosierdzia. Już Orygenes wiąże namaszczenie przez poszczącego swojej twarzy z okazywaniem miłosierdzia ${ }^{62}$. Sama zbieżność w brzmieniu słów $\dot{\alpha} \lambda \varepsilon i ́ \varphi \omega$ ('namaszczam') i $\dot{\varepsilon} \lambda \varepsilon \eta ́ n \omega v$ ('miłosierny') wyraża związek tych rzeczy ${ }^{63}$. Relacja ta staje się ściślejsza, gdy uwzględnimy zalecane przez samą Ewangelię i Ojców powiązanie postu z konkretnym

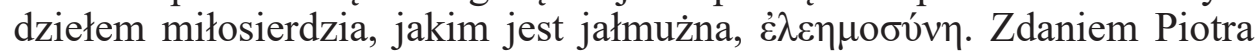
Chryzologa post „bez namaszczenia miłosierdzia” nie przyniesie korzyści zbawiennych dla ducha ${ }^{64}$.

Odwołując się do ukształtowanej już pewnie tradycji, Hilary z Poitiers zestawia zalecane w Mt 6,17 namaszczenie olejem z obmyciem twarzy

\footnotetext{
59 Por. Ambrosius Mediolanensis, De Helia et ieiunio X 36.

60 Basilius Caesariensis, De ieiunio: homilia I 2, Post jako praktyka duchowa, s. 56.

61 Origenes, Homiliae in Psalmos XXI 11.

62 Por. Origenes, Homiliae in Leviticum X 2, PSP 31/2, s. 147.

63 Por. Origenes, Homiliae in Leviticum X 2, PSP 31/2, s. 147. Słowa te pewnie występowały w oryginale greckim, który jednak zaginął, a zachowało się tłumaczenie łacińskie. Występują obok siebie np. w: Gregorius Palamas, Homiliae VII 11.

64 Petrus Chrysologus, Collectio sermonum 41, PL 52, s. 316.
} 
i każdemu gestowi przypisuje osobne znaczenie. Jak zapewnia, „pisma niebiańskie i prorockie mówią, że olej jest owocem miłosierdzia". O ile obmycie twarzy wyraża uwolnienie się od złych czynów i zdobycie „,prawości sumienia”, to jej namaszczenie - dobre uczynki, a zwłaszcza „piękno czynów miłosierdzia" ${ }^{65}$. Podobnie zdaniem późnobizantyjskiego pisarza, Grzegorza Palamasa, obmyć twarz oznacza oczyścić umysł z bezwstydnych i nieczystych myśli oraz wszelkiego zła, a namaścić głowę - czynić umysł łagodnym ${ }^{66}$.

Jak wynika z wypowiedzi Chromacjusza z Akwilei, namaszczenie olejem wyraża całą sekwencję miłosierdzia. Nie ulega wątpliwości, ,że namaszczenie głowy oznacza miłosierdzie". Człowiek zostaje namaszczony Bożym miłosierdziem, następnie sam okazuje je bliźniemu, w czego następstwie Bóg udziela mu jeszcze więcej swego zmiłowania. W zamian za miłosierdzie okazane bliźniemu, „na mocy Bożego wynagrodzenia, czujemy się jakby oblani jakimś niebieskim olejkiem przez Tego, który do nas mówi: «Błogosławieni miłosierni, albowiem oni miłosierdzia dostąpią»" (Mt 5,7) ${ }^{67}$. Jeśli pościmy, nie zaniedbując uczynków miłosierdzia względem bliźniego, sami dostępujemy Bożego zmiłowania.

Pewną odwrotnością powyższej symboliki namaszczenia jako obrazu miłosierdzia i łagodności jest rozumienie go jako zabiegu przygotowującego do walki duchowej. W komentarzach Ojców znajduje wyraz powszechne łączenie tego aktu z walkami sportowymi. Tak oto, już poza kontekstem Jezusowych zaleceń w Mt 6,17, a w duchu helleńskim, przedstawia się post jako atletyczną walkę. Bliżej nieznany autor jest przekonany, że ta walka nosi znamiona cudu. Namaszczani są do niej nie tylko mężczyźni, ale i kobiety oraz dzieci, przekraczając swoją słabą naturę. Roztacza się wolne pole przed walczącymi; okrutny przeciwnik, diabeł, może być łatwo pokonany i przepędzony; Chrystus zasiada jako sędzia, gotowy wręczyć hojną nagrodęe ${ }^{68}$.

Zbawiciel jest nie tylko przychylnym arbitrem w samej walce, ale już wcześniej zrobił On wszystko, aby Jego uczeń mógł odnieść zwycięstwo. Bazyli Wielki wskazuje na znaczenie wcielenia dla tych ascetycznych zmagań, które zresztą sam Chrystus podją:

Pan nasz umocnił postem swoje ciało, które przyjął ze względu na nas, i dopiero wtedy przyjął w nim ataki diabła; nauczył nas zatem, byśmy namasz-

65 Hilarius Pictaviensis, Commentarius in Matthaeum V 2, PSP 63, s. 65.

66 Por. Gregorius Palamas, Homiliae VII 11.

67 Chromatius Aquileiensis, Sermones XV 3, PSP 49, s. 161-162.

68 Por. Joannes Chrysostomus (?), In mediam hebdomadam ieiuniorum, PG 59, 702-703. 
czali się postami i ćwiczyli się do walk z pokusami, gdy przy pomocy głodu dał przeciwnikowi sposobność do zadania ciosu. Byłby bowiem niedostępny dla niego ze względy na wzniosłość bóstwa, gdyby przez głód nie zniżył się do tego, co ludzkie ${ }^{69}$.

W symbolice namaszczenia biskup Cezarei łączy ze sobą świecki element agonistyczny z biblijnym obrazem walki Jezusa ze złym duchem na pustyni.

Starochrześcijańscy pisarze chętnie przenoszą obraz walczącego atlety na męczennika składającego świadectwo krwi na arenie. Gdy skończyły się prześladowania, rozwija się idea „,białego męczeństwa”, przez które uczeń Chrystusa podejmuje inną, bezkrwawą walkę, przez samozaparcie $i$ ascezę. Jedna walka może przygotować do drugiej. W tym duchu Bazyli wygłasza pochwałę męczennika Gordiona, nawiązując do obrazu rozebranego i namaszczonego zapaśnika. Takim był i ten męczennik, który zanim stoczył krwawą walkę, namaścił się do niej wewnętrznie przez posty, czuwania, modlitwę i ciągłe rozważanie duchowych słów ${ }^{70}$.

Namaszczenie przez ascezę nie musi każdego sposobić do męczeństwa. Na innym miejscu biskup Cezarei w ogóle łagodzi wymowę agonistycznej symboliki. Stwierdza mianowicie, że ,post namaszcza do pobożności"’71. W ten sposób zdaje się godzić zawartą w tym obrazie symbolikę zarówno miłosierdzia i łagodności, jak i zdecydowanej walki. Pobożność zawiera $\mathrm{w}$ sobie obydwa elementy i jest nadrzędnym celem duchowych dążeń chrześcijanina.

Namaszczenie olejem może sprawiać przyjemną woń. Ten gest dokonany przenośnie, przez szczery post sięgający ducha, jest dla Jana Chryzostoma niczym namaszczenie za pomocą pachnącego olejku ( $\mu$ v́pov), którego woń prędko poczują znajdujący się w sąsiedztwie ${ }^{72}$. Tak oto poszczący nie tylko nie odpycha, ale i pociąga innych swoją postawą. Jak zauważa łaciński kaznodzieja Piotr Chryzolog, przez dobry, praktykowany w duchu Ewangelii post chrześcijanin wyraża pokorę względem Boga, a równocześnie pokazuje owoce swojej pobożności wszystkim patrzącym $^{73}$.

W ten sposób ujawnia się apostolski wymiar chrześcijańskiego postu. Uczeń Chrystusa, namaszczony olejkiem miłosierdzia i oczyszczony

69 Basilius Caesariensis, De ieiunio: homilia I 9, Post jako praktyka duchowa, s. 63.

70 Por. Basilius Caesariensis, In Gordium martyrem, PG 31, 496.

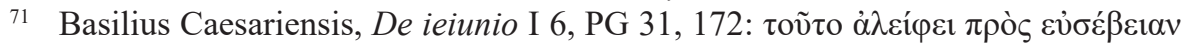
('przygotowuje do pobożności' - Post jako praktyka duchowa s. 59).

72 Por. Joannes Chrysostomus, Ad populum Antiochenum homiliae X 11, PG 49, 111.

73 Por. Eusebius Caesariensis, Commentarius in Isaiam (in Is 58,5), PG 24, 480. 
z wad, z tym większym wdziękiem przyciąga ludzi. Innymi słowy, jaśniejąc prawością sumienia, ozdobieni pięknymi czynami miłosierdzia, a w samym poście nie szukając własnej sławy, stajemy się ,i mniej śmieszni, i bardziej docenieni" 74 . Paradoksalnie nie szukając szacunku z powodu podjętych umartwień, gdy pełnimy je dobrze, zdobywamy ten szacunek niejako samoczynnie.

\section{Symbolism of the Head Anointing and Face Washing by the Fasting Christian (Mt 6:17) in Patristic Exegesis}

(summary)

In ancient commentators, we find reflection on the recommendation to anoint faces and to wash the head during fasting (Mt 6:17). By sticking to the essence of the message, and thus the evangelical encouragement to humbleness and avoiding ostentation in fasting, the Fathers consider the necessity of public fasting in some cases. Cassiodorus combines the fast held for the human show with the attitude of foolish virgins (Mt 25:1-13), who lacked the oil in their lamps, it means the attention directed on the Lord, because they did their good deeds to flatter others. For our authors, washing the face in Mt 6:17 means honesty of conscience, and above all, moral purity. The head anointing, in turn, expresses the joy of the inner man who fasts for the sake of God. Fathers see the connection of this anointing with the "oil of gladness" in Ps 45:8, with which God anoints his chosen one. The joy of fasting also comes from the many spiritual benefits that the fasting brings. The anointing with oil had a rich meaning in the biblical and ancient world, which our authors take over. It is a participation in the mystery of Christ as God's Anointed, High Priest and Head of the Mystical Body. While the face washing means getting rid of evil, in some writers the head anointing symbolizes good deeds, and above all works of mercy. The association with the athlete's anointing before the fight implies understanding the fasting as a fight. The pleasant scent of oil, in turn, indicates the apostolicity nature of Christian mortification, which draws others to the faith and imitation.

Keywords: Mt 6:17; patristic exegesis; fast; head anointing; face washing

\section{Symbolika namaszczenia głowy i obmycia twarzy przez poszczącego (Mt 6, 17) w interpretacji patrystycznej}

(streszczenie)

U starożytnych komentatorów spotykamy bogatą refleksję nad zaleceniem namaszczenia twarzy i obmycia głowy podczas postu (Mt 6,17). Trzymając się istoty przesłania, a więc ewangelicznej zachęty do pokory i wystrzegania się ostentacji w poście,

74 Hilarius Pictaviensis, Commentarius in Matthaeum V 2, PSP 63, s. 65. 
Ojcowie zastanawiają się nad koniecznością w niektórych przypadkach postu publicznego. Kasjodor łączy post odbywany na pokaz ludzki z postawą panien nierozsądnych (Mt 25,1-13), u których zabrakło oliwy w lampach, czyli uwagi skierowanej na Pana, ponieważ dobre uczynki spełniały dla zdobycia pochlebstw u innych. Obmycie twarzy w Mt 6,17 oznacza dla naszych autorów szczerość sumienia, a przede wszystkim czystość moralną polegającą na wyzbyciu się grzechów i wad. Namaszczenie głowy z kolei wyraża radość człowieka wewnętrznego, który pości ze względu na Boga. Ojcowie dostrzegają związek tego namaszczenia z „olejkiem wesela” w Ps 45,8, którym Bóg namaszcza swego wybranego. Radość postu płynie też z wielu korzyści duchowych, który przynosi post. Namaszczenie olejem miało w świecie biblijnym i starożytnym bogate znaczenie, które przejmują nasi autorzy. Jest ono udziałem w tajemnicy Chrystusa jako Pomazańca Bożego, Arcykapłana i Głowy mistycznego ciała. O ile obmycie twarzy oznacza wyzbycie się zła, to u niektórych pisarzy namaszczenie głowy symbolizuje dobre uczynki, a przede wszystkim dzieła miłosierdzia. Skojarzenie z kolei z namaszczeniem atlety przed walką każe rozumieć post jako pewne zmagania. Przyjemna woń oleju z kolei wskazuje na apostolski charakter chrześcijańskiego umartwienia, które pociąga innych do wiary i naśladownictwa.

Słowa kluczowe: Mt 6,17; patrystyczna egzegeza; post; namaszczenie głowy; obmycie twarzy

\section{Bibliografia}

\section{Źródła}

Aëtius Amidenus, Iatricorum liber XII, red. G.A. Kostomiris, Aetiu logos dodekatos, Paris 1892, s. 7-131.

Ambrosius Mediolanensis, De Helia et ieiunio, red. C. Schenkl, CSEL 36/2, Wien 1897, s. 411-465, tł. P. Jędrzejowski, Św. Ambroży z Mediolanu, O Eliaszu i poście, VoxP 34-35 (1998) s. 471-500.

Augustinus Hipponensis, De diversis quaestionibus, PL 40, 11-100.

Augustyn Hipponensis, De sermone Domini in monte, red. A. Mutzenbecher, CCL 35, Turnhout 1967, tł. C. Ryznar - J. Sulowski, Św. Augustyn, O kazaniu Pana na Górze, PSP 48, 21-130.

Basilius Caesariensis, Asceticon magnum, PG 31, 901-1305.

Basilius Caesariensis, De ieiunio: homilia I et II, PG 31, 164-197, t1. M. Przyszychowska,

Św. Bazyli Wielki, Mowy o poście, w: Post jako praktyka duchowa. Ojcowie Kościoła o poście, opr. L. Nieścior, Kraków 2019, s. 55-73.

Basilius Caesariensis, In Gordium martyrem, PG 31, 489-508.

Caesarius Arelatensis, Sermones, red. G. Morin, CCL 103-104, Turnhout 1953.

Cassiodorus, Expositio psalmorum, red. M. Adriaen, CCL 97-98, Turnhout 1958.

Chromatius Aquileiensis, Sermones, red. J. Lemarié, CCL 9A, 3-182, Turnhout 1974, tł. S. Ryznar, Św. Chromacjusz z Akwilei, Kazania i homilie, PSP 49, Warszawa 1990. Eusebius Caesariensis, Commentarius in Isaiam, PG 24, 89-526. 
Eusebius Caesariensis, Commentarius in Isaiam, red. J. Ziegler, Eusebius Werke 9, Berlin 1975.

Gregorius Palamas, Homiliae, red. P.K. Chrestou, Grigoriu tu Palama ahpanda ta erja 9, Tesaloniki 1985.

Hieronymus Stridonensis, Commentarii in Evangelium Matthaei, red. D. Hurst - M. Adriaen, CCL 117, Turnhout 1969, tł. J. Korczak, Św. Hieronim, Komentarz do Ewangelii wedtug św. Mateusza, ŹMT 46, Kraków 2008.

Hieronymus Stridonensis, Commentarii in prophetas minores, red. M. Adriaen, CCL 76-76A, Turnhout 1969-1970.

Hieronymus Stridonensis, Commentarius in Ecclesiasten, red. M. Adriaen, CCL 72, Turnhout 1959.

Hilarius Pictaviensis, Commentarius in Matthaeum, PL 9, 917-1078, tł. E. Stanula, Św. Hilary z Poitiers, Komentarz do Ewangelii wg św. Mateusza, PSP 63, s. 43-200.

Hilarius Pictaviensis, Tractatus super Psalmos, red. A. Zingerle, CSEL 22, Wien 1891.

Hippiatrica. Additamenta Londinensia ad hippiatrica Cantabrigiensia, red. K. Hoppe E. Oder, Corpus hippiatricorum Graecorum 2, Leipzig 1927, s. 253-271.

Joannes Chrysostomus (?), In mediam hebdomadam ieiuniorum, PG 59, 701-704.

Joannes Chrysostomus, Ad populum Antiochenum homiliae 1-21, PG 49, 15-222.

Joannes Chrysostomus, Expositiones in Psalmos, PG 55, 39-498.

Joannes Chrysostomus, In Matthaeum homiliae 1-90, PG 57, 13-472; 58, 471-794, tł. J. Krystyniacki - A. Baron, Homilie na Ewangelię według św. Mateusza, Kraków 2000, ŹMT 18 (cz. 1: hom. 1-40).

Origenes, Homiliae in Leviticum, red. W.A. Baehrens, Origenes Werke 6, Leipzig 1920, s. 280-507, tł. S. Kalinkowski, Orygenes, Homilie o Księdze Kapłańskiej, PSP 31/2, Warszawa 1984.

Origenes, Homiliae in Psalmos, red. L. Perrone, Origenes Werke 13, Berlin 2015.

Origenes (?), Selecta in Psalmos (fragmenta e catenis), PG 12, 1085-1320, 1409-1686.

Petrus Chrysologus, Collectio sermonum, PL 52, 183-666, tł. M. Przyszychowska, Św. Piotr Chryzolog, Mowy VII-IX, w: Post jako praktyka duchowa. Ojcowie Kościoła o poście, opr. L. Nieścior, Kraków 2019, s. 91-101.

Photius, Amphilochia, red. B. Laourdas - L.G. Westerink, Photii patriarchae Epistulae et Amphilochia, v. 3-6, Leipzig 1985-1988.

Photius, Commentarii in Matthaeum (in catenis), red. J. Reuss, Matthäus-Kommentare aus der griechischen Kirche, Berlin 1957, s. 270-337.

Photius, Epistulae, red. B. Laourdas - L.G. Westerink, Photii patriarchae Epistulae et Amphilochia, v. 1-3, Leipzig 1983-1985.

Pseudo-Joannes Chrysostomus, De ieiunio, sermones I-VII, PG 60, 711-724, tł. M. Przyszchowska, Pseudo-Jan Chryzostom, Mowy o poście, w: Post jako praktyka duchowa. Ojcowie Kościoła o poście, opr. L. Nieścior, Kraków 2019, s. 111-133. 


\section{Opracowania}

Levine E., The Theology of Fast Day Cosmetics (Mt. 6:16-18), „Journal of Ritual Studies” 13/1 (1999) s. 1-6.

Ryken L. - Wilhoit J.C. - Longman T., Stownik Symboliki Biblijnej, tt. Z. Kościuk, Warszawa 1998.

Żywica M., Post z ,,umyta i namaszczona twarzq” (Mt 6, 16-18), „Warmińskie Wiadomości Diecezjalne" 84 (2006) s. 75-78. 